\title{
MIST Ülkelerinde İthalat, İhracat ve Ekonomik Büyüme: Toda- Yamamoto Nedensellik Analizi
}

\section{Gökhan AKAR ${ }^{1}$ ve Mehmet ÖZCAN ${ }^{2}$}

Öz

Ulusal ekonomilerin dişa açık bir uluslararası ticaret politikası benimsemesinin iktisadi büyümelerine olumlu yönde katkıda bulunacağı hipotezi literatürde uzun yıllardır tartışılmakta ve büyük ölçüde kabul görmektedir. Bu bağlamda Meksika, Endonezya, Güney Kore ve Türkiye'den oluşan MIST ülkeleri ele alınmış, her bir ülke için zaman serisi yöntemlerinden Johansen eşbütünleşme ve Toda-Yamamoto nedensellik analizleri uygulanarak diş ticaret ile büyüme arasındaki ilișki incelenmiștir. Ampirik bulgulara göre geliri dıș ticaretten en çok etkilenen ülke Meksika'dır. Bununla birlikte Meksika, Endonezya ve Türkiye için dış ticarete dayalı büyüme hipotezi geçerlidir.

Anahtar Kelimeler: İhracat, İthalat, İktisadi Büyüme

\section{Imports, Exports and Economic Growth in MIST Countries: Toda-Yamamoto Causality} Analysis

\section{Abstract}

The hypothesis that an open international trade policy will contribute positively to the economic growth of the countries has been discussed and widely accepted in the literature for many years. In this context, the relationship between foreign trade and growth are discussed for the MIST countries consisting of Mexico, Indonesia, South Korea and Turkey by applying the time series methods which are Johansen co-integration and Toda-Yamamoto causality analyses. According to empirical findings, income of Mexico is the most affected by foreign trade. However, trade-led growth hypothesis is valid for Indonesia, Mexico and Turkey.

Key Words: Export, Import, Economic Growth

\section{Atıf İçin / Please Cite As:}

Akar, G. ve Özcan, M. (2020). MIST ülkelerinde ithalat, ihracat ve ekonomik büyüme: Toda-Yamamoto nedensellik analizi. Manas Sosyal Arasttrmalar Dergisi, 9(1), 47-59.

Geliş Tarihi / Received Date: 09.02.2019

Kabul Tarihi / Accepted Date: 03.06.2019

${ }^{1}$ Dr. Öğr. Üyesi - Karamanoğlu Mehmetbey Üniversitesi İktisadi ve İdari Bilimler Fakültesi, gakargakar@gmail.com ORCID: 0000-0001-8401-4052

2 Dr. Arş. Gör. - Karamanoğlu Mehmetbey Üniversitesi İktisadi ve İdari Bilimler Fakültesi, mehmetozcan@kmu.edu.tr ORCID: 0000-0001-9082-0894 


\section{Giriş}

Uluslararası ticaret teorisindeki son gelişmeler ölçek ekonomileri ve aksak rekabet ortamında izlenen ticaret modellerine yeni bir 1şık tutmuştur. Bu açıdan özellikle daha fazla yararlı olan monopolcü rekabete yönelik çalışmalar olmuştur. Bu teori, sektörler arası ticaret akışlarına dair faktör oranlarından hareketle benzer ülkeler arasında daha büyük hacimlerde ticaretin varlığını açılar (Helpman, 1987, s. 63). Ticaretin serbestleşmesini savunanlar, daha önce örneğine rastlanmamış bir refah artışı sağlayacağına inanmaktadırlar. Gelişmiş ülkelerin yurtiçi pazarlarını, gelişmekte olan ülkelerin ihracatlarına açmalarını ve serbestleştirmelerini istemektedirler. Bununla birlikte mal ve hizmetlerin akışındaki engellerin ortadan kaldırılmasıyla küreselleşmenin refah üzerinde pozitif bir etki yaratacağ1 düşünülmektedir (Stiglitz, 2006, s. 62).

Teorik olarak, ticaret ve büyüme genellikle uluslararası ticarete yönelik dışa açık bir politika ile ekonomik büyüme arasında pozitif bir ilişkiyi öngörmektedir. Bu teorik durumu destekleyen bazı nedensel etmenler bulunmaktadır. İlk olarak serbest dış ticaret rejimi, rekabeti artırmaktadır. Bir ekonomide rekabet düzeyinin artması daha etkili kaynak tahsisine yol açmaktadır. Bu durum verimliliği pozitif yönde etkilemektedir. İkinci olarak ticaretin, sermaye ve ara mal ithalatına olanak tanımasıyla ülke içerisindeki üretim kapasitesini artırarak büyüme sürecine katkı sağlaması mümkündür. Ayrıca üretim artışını teşvik eden bu ithalat gerçekleşmesine imkan tanıyan döviz için ihracat kilit bir belirleyici olarak kabul edilmektedir (Iheanacho, 2017). İhracata yönelik politikalar, uluslararası pazarlarda daha fazla yer alan ve ekonomik sınırlandırmaları aşan bir üretim yapısıyla sonuçlanmaktadır. Bu durum ölçek ekonomisinden yararlanma adına önemli bir adım olarak görülmektedir. Üretimde daha fazla kapasite kullanımı gerçekleşmesi ölçek ekonomisi avantajından yararlanarak maliyetlerin azaltılmasını sağlamaktadır. Bu dış ticaret politikasını benimseyen ülkeler fiyat açısından rekabet gücü elde ederek uluslararası rekabete cevap verebilir hale gelecektir. Bu durum aynı zamanda üretim yapısı açısından emek yoğun ülkelerde istihdamı arttırmaktadır. Son olarak uluslararası ticaretin gelişmesi, piyasalarda etkileşimi arttırarak yeni teknolojilerin ve bilginin yayılmasını sağlamaktadır. Ayrıca üretim ve verimlilik artışına yol açması da öngörülmektedir. Buna karşlık ithal ikameci politika, yerli üretimin ithalat yerine ikame edilmesiyle küçük ulusal pazarlarda ölçek ekonomisi kaybına ve ilgili ürünlerin kısmen sermaye yoğunluğuna bağlı olarak artan maliyetlere yol açmaktadır. Sonuç olarak, koruma altında devam eden ithal ikameci politikanın neden olduğu döviz tasarrufunun iç maliyeti, ihracat sayesinde döviz kazanmanın maliyetini geçecek ve aradaki fark zamanla artma eğiliminde olacaktır (Balassa, 1978, s. 181-182). Bu çalışmanın amacı ticarete dayalı büyüme hipotezinin MIST (Meksika, Endonezya, Güney Kore ve Türkiye) ülkelerinde geçerliliğini analiz etmektedir. Ayrıca bu ülkelerde ithalat, ihracat ve ekonomik büyüme arasındaki ilişkiyi incelemektir. MIST ülkeleri, son dönemde yükselen ekonomileriyle birlikte sahip oldukları nüfus ve pazar büyüklüğü açısından küresel ekonomi için önemli bir güç olarak değerlendirilmektedir. Bu açıdan çalışmanın sonuçlarının literatüre önemli katkı sağlayacağı düşünülmektedir. Çalışma üç bölümden meydana gelmektedir. Çalışmanın birinci bölümünde dış ticaret ve ekonomik büyüme ilişkisi üzerinde durulmuştur. İkinci bölümde veri ve yöntem hakkında bilgi verilerek konu ile ilgili ampirik çalısmalara yer verilmiştir. Son bölümde de ampirik sonuçlara ve değerlendirmeye yer verilmiştir.

\section{Literatür İncelemesi}

İhracata dayalı büyüme hipotezi, farklı analiz teknikleri kullanılarak birçok araştırmacı tarafindan incelenmiştir. Mevcut ampirik literatür üç gruba ayrılabilir. Bazı çalısmalarda ülkelerarası veriler ile sıra korelasyon yöntemi kullanılarak hipotez test edilmiştir (Kravis, 1970, s.869-870; Tyler, 1981, s.129; Ijirshar, 2015, s.121). İkinci grup çalısmalarda regresyon tekniği ile en küçük kareler ve panel veri yöntemleri kullanılarak yapılan çalışmalardır (Balassa, 1985; Ram, 1985; Mbaku, 1989; Alam, 1991; De Gregorio, 1992; Amirkhalkhali ve Dar, 1995; Fosu, 1996; Çetintaş ve Barişik, 2009; Furuoka, 2009; Herzer, 2010; Dreger ve Herzer, 2011; Yardımcioğlu ve Gülmez, 2013; Şahbaz, Ağır ve Yanar, 2014; Topallı ve Alagöz, 2015; Edeme, Ifelunini ve Nkalu, 2016; Ee, 2016).

Üçüncü grup çalışmalarda da zaman serisi yöntemi kullanılarak ihracat ve büyüme arasındaki ilişki incelenmiştir. Awokuse (2007), tarafından yapılan çalşsmada Bulgaristan, Polonya ve Çek Cumhuriyeti ülkeleri için ihracatın ve ithalatın ekonomik büyüme üzerindeki etkilerini incelemiştir. Çalışmada ticaretin ekonomik büyümeyi teşvik ettiği sonucuna ulaşılmışır. Chandra (2003), Hindistan'da ihracata dayalı büyüme hipotezini araştırmıştır. Değişkenler arasında çift yönlü bir nedensellik ilişkisi bulmuştur. Shihab, Soufan ve AbdulKhaliq (2014), Granger nedensellik analizini kullanarak Ürdün için 2000-2012 yıllar1 arasındaki dönemine yönelik ekonomik büyümeden ihracata doğru tek yönlü nedensellik ilişkisi tespit etmişlerdir. Elbeydi, Hamuda ve Gazda (2010) tarafindan yapılan çalışmada 1980-2007 dönemi için Libya örnekleminde ihracat ve gelir artışı arasında uzun dönemde çift yönlü nedensellik tespit edilmiştir. Ayrıca çalışmada ihracatın teşvik 
edilmesinin ekonomik büyümeye katkı sağladığı sonucuna ulaşmışlardır. Shirazi ve Manap (2004), ihracat ve ekonomik büyüme arasındaki ilişkiyi Pakistan için incelemişlerdir. Çalısmanın sonucuna göre ihracat, ithalat ve çıktı büyümesi arasında uzun vadeli bir ilişki tespit edilmiştir. Ayrıca ampirik bulgular ihracattan çıktı büyümesine tek yönlü bir nedensellik olduğunu göstermiştir. Bununla birlikte ihracat ve ithalat arasinda önemli bir nedensellik olmadığını bulmuşlardır. Raza ve Ying (2017), ihracata dayalı büyüme hipotezini TodaYamamoto ve eşbütünleşme testlerini kullanarak Pakistan için incelemişlerdir. İhracatın ekonomik büyüme ve yatırımların nedeni olduğu sonucunu bulmuşlardır. Ayrıca ekonomik büyümeden yatırımlara doğru tek yönlü nedensellik ilişkisi bulmuşlardır. Hye, Wizarat ve Lau (2013), Granger nedensellik testini kullanarak altı tane Asya ülkesi için ihracat, ithalat ve ekonomik büyüme arasındaki uzun dönemli ilişkiyi incelemişlerdir. İthalata dayalı ekonomik büyüme Bangladeş, Butan, Hindistan, Nepal, Pakistan ve Sri Lanka için geçerli olduğu sonucuna ulaşmışlardır. İhracata dayalı büyüme modelinin Pakistan hariç incelenen tüm ülkelerde geçerli olduğunu tespit etmişlerdir. Ayrıca çalışmanın sonuçlarına göre yurtiçi ve yurtdışı talebin artmasının, ekonomik büyüme ve istihdam açısından pozitif katkıda bulunduğunu ifade etmişlerdir. Nguyen (2016) tarafından yapılan çalışmada, 1990-2015 dönemi için Vietnam ekonomik büyümesi ve ihracatı arasında önemli pozitif bir ilişki bulmuştur. Konya (2004), 25 OECD ülkesi için ihracata dayalı büyüme hipotezi ile büyümeye dayalı ihracat olasılı̆̆ını Granger nedenselliğini test etmiştir. Çalışmanın sonuçlarına göre İzlanda 'da ihracat büyümenin nedeni, Kanada, Japonya ve Kore'de büyümenin ihracatın nedeni olduğunu tespit etmiştir. Ayrıca İsveç ve İngiltere için ihracat ve ekonomik büyüme arasında çift yönlü bir ilişki sonucuna ulaşmıştır. Njimanted ve Aquilas (2015) tarafından yapılan çalışmada kereste ihracatının ekonomik büyüme üzerindeki etkisini Kamerun örnekleminde Johansen eşbütünleşme ve hata düzeltme modelini kullanarak incelemişlerdir. Kereste ihracatının uzun dönemde ekonomik büyüme üzerinde olumlu bir etkiye sahip olduğu sonucuna ulaşmışlardır. Ramos (2001), ihracat, ithalat ve ekonomik büyüme arasındaki ilişkiyi Portekiz için 1865-1998 dönemine yönelik Granger nedensellik testiyle incelemiştir. Çalışmada elde edilen ampirik sonuçlara göre değişkenler arasında bir nedensellik ilişkisinin olmadığını tespit etmiştir. Ekanayake (1999), Asya'daki sekiz gelişmekte olan ülkede 1960-1997 dönemine ait ylllk verileri kullanarak ihracat ve ekonomik büyüme arasındaki nedensellik ilişkisini eş bütünleşme ve hata düzeltme modeliyle analiz etmiştir. Çalışmanın sonucunda, Hindistan, Endonezya, Kore, Pakistan, Filipinler, Sri Lanka ve Tayland için ekonomik büyüme ve ihracat arasında çift yönlü nedensellik ilişkisi tespit etmiştir. Ayrıca Malezya için ihracata dayalı büyüme hipotezinin geçerli olduğu sonucuna ulaşmıştır. Fitzova ve Zidek (2015), Granger nedensellik, eş bütünleşme ve vektör hata düzeltme modeli kullanılarak yapılan çalışmada Çek ve Slovak Cumhuriyetleri'nde ihracata dayalı büyüme hipotezinin geçerli olduğu sonucuna ulaşmışlardır. Saaed ve Hussain (2015) tarafından yapılan çalışmada Tunus için, ihracatın ithalat ve ekonomik büyüme ile arasında tek yönlü bir ilişki tespit etmişlerdir. Ayrıca Tunus'taki ekonomik büyümenin ihracata dayalı ithalatın hem de büyüme kaynaklı ithalat stratejisi tarafindan etkilendiği sonucuna ulaşmışlardır.

\section{Model, Veri ve Yöntem}

Ampirik çalşmada Endonezya, Meksika, Güney Kore ve Türkiye'ye ait gayri safi yurtiçi, hasıla $\left(\mathrm{y}_{\mathrm{t}}\right)$, toplam mal ve hizmet ihracatı $\left(\mathrm{ex}_{\mathrm{t}}\right)$ ve toplam mal ve hizmet ithalatı $\left(\mathrm{im}_{\mathrm{t}}\right)$ serilerinden faydalanılmıştır. Değişkenlerin tamamı 2010 sabit fiyatları olup yıllık frekansta Türkiye için 1987-2017 arasında, diğer ülkeler için ise 1980-2017 ylları arasında incelenmiştir. Verilerin tamamı Dünya Bankası World Development Indicators veri tabanından elde edilmiş ve serilerin e tabanında doğal logaritmaları analizlerde kullanılmıştır. Uygulamada sırasıyla önce serilerin durağanlık durumları analiz edilecek ve entegrasyon dereceleri belirlenecektir. Ardından durağan olmasını beklemediğimiz seriler kullanılarak incelenen dört ülke için eşbütünleşme testleri uygulanacak ve hata düzeltme modelleri ile uzun dönem parametre değerleri tahmin edilecektir. Son olarak her ülke için değişkenler arasındaki Granger nedensellik ilişkileri incelenecektir.

Granger ve Newbold (1974) çalışması ile keşfedilen ve ana hatları çizilen sahte regresyon probleminin ardından zaman serilerinin durağanlık durumu ekonometri uygulamalarının hemen hemen tamamında ilk incelenen konu olmuştur. Durağanlık analizi için ortaya atılan ilk birim kök testi Dickey ve Fuller (1979) çalışması ile literatürde katılmıştır. İki sene boyunca özellikle hata teriminde gözlenen otokorelasyon problemi nedeniyle eleştirilen bu test, Dickey ve Fuller (1981) çalışması ile nihai haline kavuşmuş ardından literatürde en sık başvurulan birim kök testi olmuştur. Genişletilmiş Dickey-Fuller (Augmented Dickey Fuller, ADF) birim kök testi olarak adlandırılan test, farkı alınmış zaman serisinin gecikmeli değerlerini modele eklemek kaydıyla otokorelsyon sorunundan kurtuluyor olsa da hata teriminde gözlenen bir diğer önemli problem olan değişen varyans karşısında sağllklı sonuçlar sunamamaktadır. Bu sorun, Phillips ve Perron (1988) (PP) çalışmasında Dickey ve Fuller (1981) testinin Newey ve West (1987) değişen varyans ve otokorelasyona karş1 
tutarlı kovaryans matris tahmincisi ile geliştirilmesi ile çözülmüştür. Hata teriminin klasik varsayımları sağlamamasından kaynaklanan problemlerden kaçınmak için uygulamalı çalışmalarda her iki test istatistiğinden de faydalanılmalıdır. Tablo 1 ve Tablo 2'de serilerin düzey ve farklarına uygulanan ADF ve PP birim kök test sonuçlarına yer verilmiştir. Tablo 1'de ADF ve PP test istatistikleri için hesaplanan p değerleri (Olasılık değerleri) anlamlılık düzeylerinden $(0.1,0.05,0.01)$ küçük ise ilgili serinin birim kök içerdiğini öne süren $\mathrm{H}_{0}$ boş hipotezi reddedilebilir. Bu bağlamda analize dahil edilen serilerin tamamı için serilerin durağan olmadığını öne süren boş hipotez kabul edilir. Tablo 2'deki birinci farklar için elde edilen test istatistikleri incelendiğinde serilerin tamamının birinci dereceden entegre (durağan) yani I(1) seriler oldukları görülmektedir.

Tablo 1. ADF ve PP Birim Kök Testi Sonuclar

\begin{tabular}{|c|c|c|c|c|c|c|c|c|c|c|}
\hline & Test & & $\operatorname{ly}_{t}$ & & & $\operatorname{lex}_{t}$ & & & $\lim _{t}$ & \\
\hline \multirow{6}{*}{ 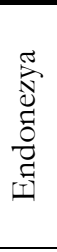 } & & 3.355 & -0.535 & -2.343 & 3.671 & -1.580 & -2.230 & 1.763 & -0.946 & -2.760 \\
\hline & $\mathrm{ADF}$ & $(0.999)$ & $(0.975)$ & $(0.439)$ & (0.999) & $(0.737)$ & $(0.484)$ & (0.999) & (0.933) & $(0.277)$ \\
\hline & & [1] & [1] & [1] & [1] & [1] & [1] & [1] & [1] & [1] \\
\hline & & & -0.345 & -2.035 & & -0.189 & -3.364 & & -1.209 & -2.997 \\
\hline & PP & & $(0.989)$ & $(0.560)$ & & $(0.999)$ & $(0.078)$ & & $(0.882)$ & (0.184) \\
\hline & & & [3] & [3] & & [3] & [3] & & [3] & [3] \\
\hline \multirow{6}{*}{$\begin{array}{l}\frac{\pi}{\pi} \\
\frac{\pi}{4} \\
\frac{x}{0} \\
\sum\end{array}$} & & 3.664 & -0.282 & -2.470 & 3.392 & -1.549 & -1.165 & 3.102 & -2.044 & -2.262 \\
\hline & $\mathrm{ADF}$ & $(0.999)$ & $(0.993)$ & $(0.389)$ & (0.999) & $(0.750)$ & $(0.900)$ & (0.999) & $(0.556)$ & $(0.471)$ \\
\hline & & {$[1]$} & [1] & [1] & [1] & [1] & [1] & [1] & [1] & [4] \\
\hline & & & -0.089 & -2.560 & & -1.68 & -1.447 & & -0.31 & -2.538 \\
\hline & PP & & $(0.999)$ & $(0.354)$ & & $(0.698)$ & $(0.789)$ & & (0.992) & $(0.363)$ \\
\hline & & & [3] & [3] & & [3] & [3] & & [3] & [3] \\
\hline \multirow{6}{*}{ 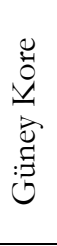 } & & 1.234 & -5.1 & -1.816 & 3.256 & -2.002 & -0.273 & 3.785 & -2.538 & -1.005 \\
\hline & $\mathrm{ADF}$ & $(0.999)$ & $(0.000)$ & $(0.645)$ & (0.999) & $(0.573)$ & (0.994) & (0.999) & $(0.363)$ & (0.924) \\
\hline & & [3] & [2] & [2] & [1] & [1] & [1] & [2] & [2] & [2] \\
\hline & & & -7.352 & -0.662 & & -2.076 & 0.262 & & -1.344 & -1.185 \\
\hline & PP & & $(0.000)$ & $(0.965)$ & & $(0.543)$ & (0.999) & & $(0.829)$ & $(0.892)$ \\
\hline & & & [3] & [3] & & [3] & [3] & & [3] & [3] \\
\hline \multirow{6}{*}{ 㞭 } & & 3.787 & 1.408 & -1.915 & 3.78 & -2.041 & -1.904 & 3.067 & -1.456 & -2.295 \\
\hline & $\mathrm{ADF}$ & $(0.999)$ & $(0.999)$ & $(0.606)$ & (0.999) & $(0.557)$ & $(0.610)$ & (0.999) & $(0.782)$ & $(0.459)$ \\
\hline & & [1] & [4] & [1] & [1] & [1] & [1] & [1] & [1] & [1] \\
\hline & & & 0.906 & -2.179 & & -1.318 & -1.706 & & -1.107 & -2.674 \\
\hline & PP & & $(0.999)$ & $(0.504)$ & & $(0.835)$ & $(0.686)$ & & (0.906) & $(0.313)$ \\
\hline & & & [2] & [2] & & [2] & [2] & & [2] & [2] \\
\hline
\end{tabular}

- Yukarıda her bir değişken için 3 adet sütun tanımlanmıştır. Bu sütunlar sırasıyla yalın Dickey-Fuller (DF) modeli, kesme içeren DF modeli ve hem kesme hem de trend içeren DF modelleri ile elde edilen test istatistiği değerlerini vermektedir. PP birim kök testi için yalın DF modeli tanımlı değildir.

- Parantez içindeki değerler ilgili istatistiğin olasıllk değerini (p-value) ifade etmektedir.

- Birim kök testleri için uygun gecikme sayısı Akaike Bilgi Kriterine göre belirlenmiş olup, en yüksek gecikme 5 olarak alınmıştır. 
Tablo 2. Serilerin Birinci Farklarmm ADF ve PP Birim Kök Testi Sonuclar

\begin{tabular}{|c|c|c|c|c|c|c|c|c|c|c|}
\hline & Test & & $\Delta \mathrm{ly}_{\mathrm{t}}$ & & & $\Delta \operatorname{lex}_{\mathrm{t}}$ & & & $\Delta \lim _{t}$ & \\
\hline \multirow{6}{*}{ 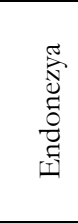 } & \multirow{3}{*}{$\mathrm{ADF}$} & -1.655 & -3.58 & -3.517 & -1.875 & -4.703 & -4.881 & -3.883 & -4.527 & -4.461 \\
\hline & & $(0.708)$ & $(0.048)$ & $(0.056)$ & $(0.622)$ & $(0.000)$ & $(0.000)$ & $(0.025)$ & $(0.000)$ & $(0.000)$ \\
\hline & & {$[1]$} & [1] & [1] & [2] & [1] & [1] & [1] & [1] & [1] \\
\hline & \multirow{3}{*}{ PP } & & -4.593 & -4.521 & & -7.414 & \begin{tabular}{|l}
-7.299 \\
\end{tabular} & & -6.008 & $\begin{array}{l}-5.897 \\
\end{array}$ \\
\hline & & & $(0.000)$ & $(0.000)$ & & $(0.000)$ & $(0.000)$ & & $(0.000)$ & $(0.000)$ \\
\hline & & & [3] & [3] & & [3] & [3] & & [3] & [3] \\
\hline \multirow{6}{*}{ 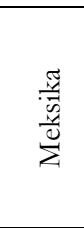 } & \multirow{3}{*}{$\mathrm{ADF}$} & -2.231 & -4.568 & -4.51 & -1.972 & -3.367 & -3.65 & -1.545 & -3.65 & -4.661 \\
\hline & & $(0.483)$ & $(0.000)$ & $(0.000)$ & $(0.584)$ & $(0.078)$ & $(0.043)$ & $(0.751)$ & (0.043) & $(0.000)$ \\
\hline & & [1] & [1] & [1] & [1] & [1] & [1] & [4] & [1] & [1] \\
\hline & \multirow{3}{*}{ PP } & & -6.56 & -6.555 & & -5.216 & -5.411 & & -4.892 & -4.914 \\
\hline & & & $(0.000)$ & $(0.000)$ & & $(0.000)$ & $(0.000)$ & & $(0.000)$ & $(0.000)$ \\
\hline & & & [3] & [3] & & [3] & [3] & & [3] & [3] \\
\hline \multirow{6}{*}{ 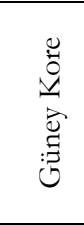 } & \multirow{3}{*}{$\mathrm{ADF}$} & -1.554 & -0.818 & -5.603 & -0.895 & -3.331 & -4.52 & -0.793 & -5.232 & -6.788 \\
\hline & & $(0.747)$ & $(0.951)$ & $(0.000)$ & $(0.940)$ & $(0.083)$ & $(0.000)$ & (0.953) & $(0.000)$ & $(0.000)$ \\
\hline & & [4] & [4] & [1] & [3] & [1] & [1] & [4] & [1] & [1] \\
\hline & \multirow{3}{*}{ PP } & & -3.935 & -7.377 & & -4.809 & -5.236 & & -5.678 & -5.91 \\
\hline & & & $(0.022)$ & $(0.000)$ & & $(0.000)$ & $(0.000)$ & & $(0.000)$ & $(0.000)$ \\
\hline & & & [3] & [3] & & [3] & [3] & & [3] & {$[3]$} \\
\hline \multirow{6}{*}{ 总 } & \multirow{3}{*}{$\mathrm{ADF}$} & -1.642 & -3.423 & -4.021 & -1.644 & -3.456 & -3.986 & -1.821 & -4.513 & -4.746 \\
\hline & & $(0.710)$ & $(0.073)$ & $(0.019)$ & $(0.709)$ & $(0.068)$ & $(0.021)$ & $(0.641)$ & $(0.000)$ & $(0.000)$ \\
\hline & & {$[1]$} & [1] & [3] & [1] & [1] & {$[1]$} & {$[2]$} & {$[1]$} & [1] \\
\hline & \multirow{3}{*}{\multicolumn{2}{|c|}{ PP }} & -5.687 & -5.8 & & -5.646 & -5.592 & & -7.486 & -7.81 \\
\hline & & & $(0.000)$ & $(0.000)$ & & $(0.000)$ & $(0.000)$ & & $(0.000)$ & $(0.000)$ \\
\hline & & & [2] & [2] & & {$[2]$} & {$[2]$} & & {$[2]$} & [2] \\
\hline \multicolumn{11}{|c|}{$\begin{array}{l}\text { - Yukarıda her bir değişken için } 3 \text { adet sütun tanımlanmıştır. Bu sütunlar sırasıyla yalın Dickey-Fuller(DF) modeli, kesme içeren } \\
\text { DF modeli ve hem kesme hem de trend içeren DF modelleri ile elde edilen test istatistiği değerlerini vermektedir. PP birim kök } \\
\text { testi için yalın DF modeli tanımlı değildir. } \\
\text { - Parantez içindeki değerler ilgili istatistiğin olasılık değerini (p-value) ifade etmektedir. } \\
\text { - Birim kök testleri için uygun gecikme sayısı Akaike Bilgi Kriterine göre belirlenmiş olup, en yüksek gecikme } 5 \text { olarak } \\
\text { alınmışır. }\end{array}$} \\
\hline
\end{tabular}

Durağanlık analizinin ardından gerçekleştirilecek eşbütünleşme ve nedensellik analizlerinin tamamı vektör otoregresif modelleri (Vector autoregression model, VAR) temel aldığından her bir ülke adına kurulacak VAR modeli için uygun gecikme değerlerinin belirlenmesi gerekmektedir. Bu amaç için bilgi kriterlerinden faydalanılmaktadır. Altı gecikmeye kadar hesaplanan Akaike (AIC), Hannan-Quinn (HQ) ve Bayesyen (BIC) bilgi kriteri değerleri Tablo 3'de verilmiştir. Sonuçlara göre Endonezya için kurulacak VAR modelinde 2 gecikme baz alınması gerekirken diğer ülkeler için bir gecikmeli VAR modeli kurulmalıdır.

Tablo 3. VAR Modeli için Uygun Gecikme Değerinin Belirlenmesi

\begin{tabular}{ccccccc}
\hline \multirow{5}{*}{ Endonezya } & \multirow{2}{*}{ Bilgi Kriterleri } & \multicolumn{5}{c}{ Gecikme Değerleri } \\
\cline { 3 - 7 } & AIC & -16.359 & $-16.618^{*}$ & -16.360 & -16.104 & -16.140 \\
& HQ & -16.176 & $-16.297^{*}$ & -15.902 & -15.509 & -15.408 \\
& BIC & $-15.815^{*}$ & -15.665 & -15.000 & -14.335 & -13.964 \\
\hline \multirow{3}{*}{ Meksika } & AIC & $-17.724^{*}$ & -17.345 & -17.084 & -16.883 & -17.454 \\
& HQ & $-17.540^{*}$ & -17.025 & -16.627 & -16.288 & -16.722 \\
& BIC & $-17.179^{*}$ & -16.393 & -15.724 & -15.115 & -15.277 \\
\hline \multirow{2}{*}{ G. Kore } & AIC & $-18.816^{*}$ & -18.714 & -18.630 & -18.587 & -18.606 \\
& HQ & $-18.633^{*}$ & -18.393 & -18.172 & -17.992 & -17.874 \\
& BIC & $-18.272^{*}$ & -17.761 & -17.270 & -16.819 & -16.429 \\
\hline \multirow{2}{*}{ Türkiye } & AIC & $-17.858^{*}$ & -17.620 & -17.160 & -16.995 & -16.740 \\
& HQ & $-17.690^{*}$ & -17.327 & -16.742 & -16.452 & -16.071 \\
& BIC & $-17.277^{*}$ & -16.604 & -15.708 & -15.108 & -14.418 \\
\hline
\end{tabular}

-Maksimum gecikme değeri 5 olarak seçilmiş ve her bir gecikme değeri için bilgi kriterleri hesaplanmıştır. İlgili bilgi kriterinin seçtiği gecikme $(*)$ ile işaretlenmiştir. 
Hesaplanan gecikme değerlerine göre her bir ülke için eşbütünleşme ve nedensellik analizlerinde temel alınacak VAR modelleri şu şekildedir:

Endonezya için 2 gecikmeli VAR modeli:

$$
\left(\begin{array}{c}
\operatorname{ly}_{\mathrm{t}} \\
\operatorname{lex}_{\mathrm{t}} \\
\lim _{\mathrm{t}}
\end{array}\right)=\left(\begin{array}{l}
\mathrm{c}_{1} \\
\mathrm{c}_{2} \\
\mathrm{c}_{3}
\end{array}\right)+\left(\begin{array}{lll}
\pi_{11}^{1} & \pi_{12}^{1} & \pi_{13}^{1} \\
\pi_{21}^{1} & \pi_{22}^{1} & \pi_{23}^{1} \\
\pi_{31}^{1} & \pi_{31}^{1} & \pi_{33}^{1}
\end{array}\right)\left(\begin{array}{c}
\operatorname{ly}_{\mathrm{t}-1} \\
\operatorname{lex}_{\mathrm{t}-1} \\
\lim _{\mathrm{t}-1}
\end{array}\right)+\left(\begin{array}{ccc}
\pi_{11}^{2} & \pi_{12}^{2} & \pi_{13}^{2} \\
\pi_{21}^{2} & \pi_{22}^{2} & \pi_{23}^{2} \\
\pi_{31}^{2} & \pi_{31}^{2} & \pi_{33}^{2}
\end{array}\right)\left(\begin{array}{c}
\operatorname{ly}_{\mathrm{t}-2} \\
\operatorname{lex}_{\mathrm{t}-2} \\
\lim _{\mathrm{t}-2}
\end{array}\right)+\left(\begin{array}{c}
\varepsilon_{1 \mathrm{t}} \\
\varepsilon_{2 \mathrm{t}} \\
\varepsilon_{3 \mathrm{t}}
\end{array}\right)
$$

Meksika, Güney Kore ve Türkiye için tek gecikmeli VAR modeli:

$$
\left(\begin{array}{c}
\operatorname{ly}_{\mathrm{t}} \\
\operatorname{lex}_{\mathrm{t}} \\
\lim _{\mathrm{t}}
\end{array}\right)=\left(\begin{array}{l}
\mathrm{a}_{1} \\
\mathrm{a}_{2} \\
\mathrm{a}_{3}
\end{array}\right)+\left(\begin{array}{lll}
\psi_{11}^{1} & \psi_{12}^{1} & \psi_{13}^{1} \\
\psi_{21}^{1} & \psi_{22}^{1} & \psi_{23}^{1} \\
\psi_{31}^{1} & \psi_{31}^{1} & \psi_{33}^{1}
\end{array}\right)\left(\begin{array}{c}
\operatorname{ly}_{\mathrm{t}-1} \\
\operatorname{lex}_{\mathrm{t}-1} \\
\lim _{\mathrm{t}-1}
\end{array}\right)+\left(\begin{array}{c}
v_{1 \mathrm{t}} \\
v_{2 \mathrm{t}} \\
v_{3 \mathrm{t}}
\end{array}\right)
$$

Model (1) ve Model (2)'de yer alan $\varepsilon_{\mathrm{t}}$ ve $v_{\mathrm{t}}$ klasik varsayımların tamamını sağlayan hata terimleridir.

Nelson ve Plosser (1982) çalısması makro iktisadi zaman serilerin nerdeyse tamamının durağan olmadığını açıkça göstermiştir. Bu sebeple durağanlık kavramının ortaya çıkardığı sahte regresyon problemine çözüm aranması elzem olmuştur. Bu hususta ilk adım Engle ve Granger (1987) çalışması ile atılmış ve literatür eşbütünleşme kavramı ile tanışmıştır. Granger temsili teorisine göre, iki değişkenli bir regresyon modelindeki hata terimi değişkenlerin bir doğrusal kombinasyonudur ve eğer hata terimi durağansa bu iki seri de eşbütünleşiktir. Buna ek olarak eğer iki seri eşbütünleşik ise bu seriler arasında uzun dönemli bir ilişki vardır ve tahmin edilen regresyon modelinin parametrelerine uzun dönemde güvenilebilir. Ayrıca kısa dönemde değişkenler arasında gözlenen dengesizliğin hata düzeltme mekanizması tarafından düzeltilmesi beklenir. $\mathrm{Bu}$ mekanizma hata düzeltme modelinde yer alan tek gecikmeli kalıntı serisinin parametresi tarafindan temsil edilmekte ve bu parametre tahminin üç şartı sağlaması gerekmektedir. Bu şartlar; parametre tahminin sıfır ile bir arasında bir değer alması, negatif olması ve istatistiki olarak anlamlı olmasıdır.

Engle ve Granger (1987) eşbütünleşme yönteminin iki önemli sorunundan bahsedilebilir. Bunlardan ilki, yöntemin sadece bir bağımlı bir bağımsız iki değissken içeren modeller için sağlıklı sonuçlar vermesidir. İkinci sorun ise serilerin eşbütünleşik olduğu sonucuna ulaşıldıktan sonra modeldeki bağımlı değişken ile bağımsız değişkenin yer değiştirmesi durumunda serilerin eşbütünleşik olmadığı gibi çelişkili neticelere ulaşılmasıdır. Bu gibi sorunlara cevap olarak Johansen (1988) ikiden çok değişken içeren sistemler için VAR modellerine dayalı bir den çok eşbütünleşme vektörünün maksimum olabilirlik yöntemi ile tahmin edilebildiği bir yöntem geliştirmiştir. $\mathrm{Bu}$ yönteme göre $\mathrm{X}_{t}=\left(\mathrm{l}_{\mathrm{t}}, \operatorname{lex}_{\mathrm{t}}, \lim _{\mathrm{t}}\right)^{\prime}$ birinci derece durağan serilerden oluşan bir değişkenler vektörü olmak üzere aşağıdaki gibi bir VAR modeli kurulabilir:

$$
\mathrm{X}_{\mathrm{t}}=\mathrm{c}+\Pi_{1} \mathrm{X}_{\mathrm{t}-1}+\Pi_{2} \mathrm{X}_{\mathrm{t}-1}+\cdots+\Pi_{\mathrm{p}} \mathrm{X}_{\mathrm{t}-\mathrm{p}}+\mathrm{e}_{\mathrm{t}}
$$

Burada $e_{t}(3 \times 1)$ hata vektörüdür. p değeri ise Endonezya için 2 diğer ülkeler için 1'dir. Model (3)'den hareketle aşağıdaki eşitlik oluşturulabilir:

$$
\Delta \mathrm{X}_{\mathrm{t}}=\mu+\Gamma \mathrm{X}_{\mathrm{t}-1}+\sum_{\mathrm{i}=1}^{\mathrm{p}-1} \mathrm{~A}_{\mathrm{i}} \Delta \mathrm{X}_{\mathrm{t}-\mathrm{i}}+\eta_{\mathrm{t}}
$$

Bu eşitlikte $\eta_{\mathrm{t}}$ klasik varsayımları sağlayan hata terimleri vektörüdür. Model (4) özünde Dickey-Fuller modelinin çok değişkenli bir formudur. Burada $\Gamma$ matrisi bir katsayılar matrisi olup $(3 \times 3)$ boyutundadır ve aşağıdaki gibi ifade edilir:

$$
\Gamma=\mathrm{I}-\Pi_{1}-\Pi_{2}-\cdots-\Pi_{\mathrm{p}}
$$

Г'nin rank1 değişken sayısından yani 3'den küçük olmak üzere $(r<3)$ boyutları $(3 \times r)$ olan iki matrisin çarpımı olarak ifade edilebilir $\Gamma=\alpha \beta^{\prime} . \Delta X_{t}$ 'nin durağan ancak $X_{t}$ 'nin durağan olmadığı durumda değişkenlerin doğrusal bir kombinasyonunu temsil eden $\beta^{\prime} X_{t}$ bir durağan süreçtir. Öyleyse Granger'a göre $\mathrm{X}_{\mathrm{t}}$ değişkenleri $\beta$ matrisi ile birlikte eşbütünleşiktir. $\beta$ matrisinin her bir kolonu eşbütünleşme vektörleridir. $\alpha$ ise vektör hata düzeltme modellerinde yer alan hata düzeltme parametrelerini içermektedir. Bu noktada $\Gamma$ matrisinin rankı (r) sistemin eşbütünleşme durumu hakkında bilgi verir. $n$ değişken sayısı olmak üzere eğer $\mathrm{r}=\mathrm{n}$ ise sistemdeki tüm değişkenlerin hali hazırda durağan olduğu yani eşbütünleşme ilişkisine ihtiyaç duyulmadığı anlaşılmalıdır. Bunun aksine rank sıfıra eşit ise değişkenler arasında herhangi bir eşbütünleşme yoktur sonucuna varılabilir. $\mathrm{Bu}$ sebeple Johansen (1988) testlerinde $\mathrm{r}=0$ yokluk hipotezleri reddedilebilmelidir. $\mathrm{r}<\mathrm{n}$ olması durumunda ise $\Gamma$ matrisinin rankı kadar sistemde eşbütünleşme ilişkisi 
mevcuttur. Johansen iki adet eşbütünleşme test istatistiği sunmuştur. Bunlar maksimum özdeğer testi ve iz testi adı ile anılmakta ve aşağıdaki gibi ifade edilmektedirler:

$$
\begin{gathered}
\mathrm{J}_{\mathrm{maks}}=-\mathrm{T} \ln \left(1-\hat{\lambda}_{\mathrm{r}+1}\right) \\
\mathrm{J}_{\mathrm{iz}}=-\mathrm{T} \sum_{\mathrm{i}=\mathrm{r}+1}^{\mathrm{n}}\left(1-\hat{\lambda}_{\mathrm{i}}\right)
\end{gathered}
$$

Bu iki eşitlikte T gözlem sayısını, $\lambda$ ise $\Delta \mathrm{X}_{\mathrm{t}}$ ile $\mathrm{X}_{\mathrm{t}-1}$ arasındaki kanonik korelasyonları temsil etmektedir.

$l_{t}, \operatorname{lex}_{t}, \lim _{t}$ değişkenlerinin oluşturduğu sistemin her bir ülke için Johansen eşbütünleşme testleri uygulanmış ve sonuçlar Tablo 4'de özetlenmiştir:

\begin{tabular}{|c|c|c|c|c|c|c|}
\hline & \multicolumn{3}{|c|}{ Maksimum Özdeğer Testi } & \multicolumn{3}{|c|}{$\overline{\text { İz Testi }}$} \\
\hline & $\begin{array}{c}\text { Yokluk } \\
\text { Hipotezi }\end{array}$ & Test İstatistiği & $\begin{array}{c}\% 5 \text { Kritik } \\
\text { Değer }\end{array}$ & $\begin{array}{l}\text { Yokluk } \\
\text { Hipotezi }\end{array}$ & Test İstatistiği & $\begin{array}{c}\% 5 \text { Kritik } \\
\text { Değer }\end{array}$ \\
\hline \multirow{3}{*}{ Endonezya } & $\mathrm{H}_{0}: \mathrm{r}=0$ & 21.92 & 22.00 & $\mathrm{H}_{0}: \mathrm{r}=0$ & $46.55^{*}$ & 34.91 \\
\hline & $\mathrm{H}_{0}: \mathrm{r}=1$ & 16.88 & 15.67 & $\mathrm{H}_{0}: \mathrm{r}>1$ & $24.63^{*}$ & 19.96 \\
\hline & $\mathrm{H}_{0}: \mathrm{r}=2$ & 7.75 & 9.24 & $\mathrm{H}_{0}: \mathrm{r}>2$ & 7.75 & 9.24 \\
\hline \multirow{3}{*}{ Meksika } & $\mathrm{H}_{0}: \mathrm{r}=0$ & $32.62 *$ & 22.00 & $\mathrm{H}_{0}: \mathrm{r}=0$ & $52.34^{*}$ & 34.91 \\
\hline & $\mathrm{H}_{0}: \mathrm{r}=1$ & $16.11^{*}$ & 15.67 & $\mathrm{H}_{0}: \mathrm{r}>1$ & $19.72^{*}$ & 19.96 \\
\hline & $\mathrm{H}_{0}: \mathrm{r}=2$ & 3.61 & 9.24 & $\mathrm{H}_{0}: \mathrm{r}>2$ & 3.61 & 9.24 \\
\hline \multirow{3}{*}{ G. Kore } & $\mathrm{H}_{0}: \mathrm{r}=0$ & $35.47 *$ & 22.00 & $\mathrm{H}_{0}: \mathrm{r}=0$ & $62.39 *$ & 34.91 \\
\hline & $\mathrm{H}_{0}: \mathrm{r}=1$ & $20.39 *$ & 15.67 & $\mathrm{H}_{0}: \mathrm{r}>1$ & $26.91 *$ & 19.96 \\
\hline & $\mathrm{H}_{0}: \mathrm{r}=2$ & 6.53 & 9.24 & $\mathrm{H}_{0}: \mathrm{r}>2$ & 6.53 & 9.24 \\
\hline \multirow{3}{*}{ Türkiye } & $\mathrm{H}_{0}: \mathrm{r}=0$ & 18.57 & 22.00 & $\mathrm{H}_{0}: \mathrm{r}=0$ & $38.11^{*}$ & 34.91 \\
\hline & $\mathrm{H}_{0}: \mathrm{r}=1$ & 14.03 & 15.67 & $\mathrm{H}_{0}: \mathrm{r}>1$ & 19.55 & 19.96 \\
\hline & $\mathrm{H}_{0}: \mathrm{r}=2$ & 5.51 & 9.24 & $\mathrm{H}_{0}: \mathrm{r}>2$ & 5.51 & 9.24 \\
\hline
\end{tabular}

Tablo 4. Johansen Eşbütünleşme Testleri Sonucları

-Yokluk hipotezinin reddedilebildiği test istatistikleri $(*)$ ile işaretlenmiştir.

Tablo 4'deki sonuçlara göre her bir ülke için $\mathrm{H}_{0}: \mathrm{r}=0$ yokluk hipotezi reddedilebilmiştir. Öyleyse her ülke için en az bir adet istatistiki olarak anlamlı eşbütünleşme vektörünün varlı̆̆ından emin olunabilir. Bu durumda her ülke için hata düzeltme modeli ve uzun dönem ilişki katsayıları tahmin edilebilir. ly değişkeninin temel alındığı, her bir ülke için tahmin edilen hata düzeltme modelleri Tablo 5'de özetlenmiştir:

Tablo 5. Hata Düzeltme Modelleri Tahmin Sonuçlar

\begin{tabular}{ccccc}
\hline & \multicolumn{5}{c}{ Bağıml Değişken: $\Delta \mathrm{ly}_{\mathrm{t}}$} & $\Delta \lim _{\mathrm{t}-1}$ & $\varepsilon_{\mathrm{t}-1}$ \\
\hline \multirow{2}{*}{ Endonezya } & $\Delta \mathrm{ly}_{\mathrm{t}-1}$ & $\Delta \operatorname{lex}_{\mathrm{t}-1}$ & -0.0301 & 0.0225 \\
& 0.6307 & 0.0087 & $(0.7028)$ & $(0.1673)$ \\
\hline \multirow{2}{*}{ Meksika } & $(0.0004)$ & $(0.9313)$ & 0.0798 & $(0.0080$ \\
& -0.2361 & 0.2209 & 0.1325 & -0.0002 \\
\hline \multirow{2}{*}{ G. Kore } & $(0.4083)$ & $(0.0023)$ & $(0.1249)$ & $(0.0000)$ \\
\hline \multirow{2}{*}{ Türkiye } & -0.6243 & -0.0912 & -0.5420 & -0.0883 \\
& $(0.0411)$ & $(0.1756)$ & $(0.0010)$ & $(0.0030)$ \\
\hline
\end{tabular}

-Tablodaki parantez içerisindeki değerler ilgili değişkene ait parametre tahminin t istatistiği olasılık değeridir. 
Hata düzeltme modelleri kısa dönem ilişki katsayılarını ve hata düzeltme terimini içermektedir. Buna göre

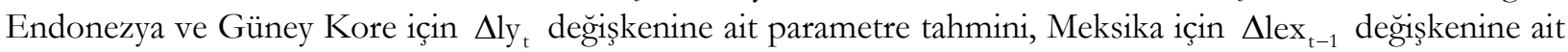
parametre tahmini Türkiye için ise hem $\Delta \mathrm{ly}_{\mathrm{t}}$ hem de $\Delta \lim _{\mathrm{t}-1}$ değişkenine ait parametre tahmini $\% 5$ anlamll11k düzeyi için istatistiki olarak anlamlı bulunmuştur. Hata düzeltme modellerinin ana odak noktası hata düzeltme katsayılarıdır. Bu katsayı tahminlerinin istatistiki olarak anlaml, negatif ve sifir ile bir arasinda yer almas1 beklenir. Bu şartları sadece Güney Kore ve Türkiye'ye ait hata düzeltme katsayı tahminleri sağlamaktadır. Dolayısıyla hata düzeltme mekanizması Türkiye ve Güney Kore için çalışmaktadır. Ancak uyarlama hızı Güney Kore için onbinde iki gibi oldukça düşük bir değerdir. Ancak Türkiye için kısa dönem dengesizliklerinin yılda yaklaşık \%9'unun giderildiği yorumu yapılabilir. $\mathrm{l}_{\mathrm{t}}$ için değişkenler arasındaki uzun dönem ilişki parametreleri tahminleri Tablo 6'da verilmiştir:

Tablo 6. Uzun Dönem Parametre Tabminleri

\begin{tabular}{cccc}
\hline & \multicolumn{2}{c}{ Bağı̆lı Değişken: ly $_{t}$} & $\lim _{t}$ \\
\hline \multirow{2}{*}{ Endonezya } & 3.3540 & $\operatorname{lex}_{t}$ & -3.2620 \\
& $(0.0030)$ & 4.2060 & $(0.0040)$ \\
\hline \multirow{2}{*}{ Meksika } & 6.3870 & $(0.0000)$ & -6.5310 \\
& $(0.0000)$ & 7.7110 & $(0.0000)$ \\
\hline \multirow{2}{*}{ G. Kore } & 6.1970 & $(0.0000)$ & -2.2430 \\
\multirow{2}{*}{ Türkiye } & $(0.0000)$ & 0.7750 & $(0.0360)$ \\
\hline
\end{tabular}

-Tablodaki parantez içerisindeki değerler ilgili değişkene ait parametre tahminin t istatistiği olasıllk değeridir.

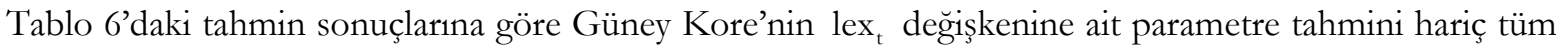
ülkeler için uzun dönem parametre tahminleri istatistiki olarak anlamlıdır. İthalatın geliri düşürmesi, ihracatın ise gelir üzerinde pozitif bir etkiye sahip olması beklenmektedir. Tablo 6 incelendiğinde her ülkenin parametre işaret tahminleri de iktisadi beklentilere uygundur. Ülke bazında yorumlanacak olursa geliri dış ticaretten en çok etkilenen ülke Meksika'dır. Bu ülke için ihracatın \%1 büyümesi geliri \% $\%$.7 arttırırken, ithalatın \%1 büyümesi geliri \%6.5 düşürmektedir. Türkiye için en dikkat çekici sonuç ithalat ve ihracat için tahmin edilen parametre mutlak değerlerinin birbirine çok yakın bulunmasıdır. Güney Kore'nin istatistiki olarak anlamsız bulunan parametre tahmini bir yana bırakılırsa diğer ülkeler için ihracatın gelir üzerindeki olumlu etkisi ithalatın olumsuz etkisinden daha fazladır. Ancak Türkiye için bu fark oldukça düşüktür. Ekonometri literatüründeki bir diğer önemli analiz nedensellik araştırmalarıdır. Nedensellik tartısmaları antik çağlara kadar dayanmakla beraber nedensellik, üzerinde mutabık kalınmış ortak bir tanımlaması olmayan bir kavramdır. Bu sebeple kantitatif iktisadi analize özgü bir nedensellik tanımlaması yapılmalı ve bu tanım üzerinden bir analiz geliştirilmelidir. Ekonometri çerçevesinde nedensellik tanımını yapan ilk çalışma Granger (1969)'dur. Dikkat edilirse ekonometride nedensellik kavramının tartışılması durağanlık ve eşbütünleşme gibi kavramlardan çok öncedir. Granger'ın nedensellik tanımı basit haliyle özetlenecek olursa; eğer bir $x_{t}$ değişkeni $y_{t}$ değişkeninin öngörü performansını iyileştiriyorsa $x_{t}, y_{t}$ 'nin Granger nedenidir. Bu çalışmada incelediğimiz değişkenleri kullanarak daha geniş bir tanımı şu şekilde yapabiliriz:

$\Omega_{\mathrm{t}}$ içerisinde $\left(\mathrm{l}_{\mathrm{t}}, \ldots, \mathrm{l}_{\mathrm{t}-\mathrm{j}}, \operatorname{lex}_{\mathrm{t}}, \ldots, \mathrm{lex}_{\mathrm{t}-\mathrm{i}}\right)$ değişenlerini barındıran bir bilgi kümesi olsun. Eğer $\mathrm{ly}_{\mathrm{t}+\mathrm{h}}$ 'nin $\Omega_{\mathrm{t}}$ 'ye dayanan optimal tahmincisinin varyans1, $\mathrm{l}_{\mathrm{t}}$ 'nin kendi gecikmeli değerlerine dayanan optimal tahmincisinin varyansından küçükse lex ${ }_{t}$, ly 'nin Granger nedenidir. Daha matematiksel olarak,

$$
\text { lex } \mathrm{t}_{\mathrm{t}} \text { Granger nedenidir } \mathrm{ly}_{\mathrm{t}}{ }^{\prime} \text { nin } \Leftrightarrow \sigma_{1}^{2}\left(\mathrm{ly}_{\mathrm{t}}: \mathrm{ly}_{\mathrm{t}-\mathrm{j}}, \operatorname{lex}_{\mathrm{t}-\mathrm{i}}\right)<\sigma_{2}^{2}\left(\mathrm{ly}_{\mathrm{t}}: \mathrm{ly}_{\mathrm{t}-\mathrm{j}}\right)
$$

Burada $i$ ve $j=1,2, \ldots, p$ 'dir ve $\sigma^{2}$ öngörü hata varyansını temsil etmektedir (Foresti, 2006 s.3).

Granger nedensellik testi özünde VAR modelindeki ilgili denklemin bazı parametrelerine getirilen sıfir kısıtının test edilmesidir. Örneğimizden hareket edersek iki değişken ve iki gecikme için kurulmuş bir VAR modeli için; 


$$
\left(\begin{array}{c}
\mathrm{ly}_{\mathrm{t}} \\
l \mathrm{le}_{\mathrm{t}}
\end{array}\right)=\left(\begin{array}{l}
\mathrm{a}_{1} \\
\mathrm{a}_{2}
\end{array}\right)+\left(\begin{array}{cc}
\psi_{11}^{1} & \psi_{12}^{1} \\
\psi_{21}^{1} & \psi_{22}^{1}
\end{array}\right)\left(\begin{array}{c}
\mathrm{ly}_{\mathrm{t}-1} \\
\operatorname{lex}_{\mathrm{t}-1}
\end{array}\right)+\left(\begin{array}{cc}
\psi_{11}^{2} & \psi_{12}^{2} \\
\psi_{21}^{2} & \psi_{22}^{2}
\end{array}\right)\left(\begin{array}{c}
\mathrm{ly}_{\mathrm{t}-2} \\
l \mathrm{~lx}_{\mathrm{t}-2}
\end{array}\right)+\left(\begin{array}{c}
v_{1 \mathrm{t}} \\
v_{2 \mathrm{t}}
\end{array}\right)
$$

yokluk hipotezleri;

$$
\begin{aligned}
& \mathrm{H}_{0}^{1}: \psi_{12}^{1}=\psi_{12}^{2}=0 ; \text { lex }_{\mathrm{t}} \text { Granger nedeni değildir } \mathrm{ly}_{\mathrm{t}}{ }_{\mathrm{t}} \text { nin } \\
& \mathrm{H}_{0}^{2}: \psi_{21}^{1}=\psi_{21}^{2}=0 ; \mathrm{y}_{\mathrm{t}} \text { Granger nedeni değildir lex }{ }_{\mathrm{t}}{ }^{\prime} \text { nin }
\end{aligned}
$$

şeklindedir. $\mathrm{H}_{0}^{1}$ ve $\mathrm{H}_{0}^{2}$ için kısıtlanmış modeller:

$$
\left(\begin{array}{l}
l y_{t} \\
l x_{t}
\end{array}\right)=\left(\begin{array}{l}
a_{1} \\
a_{2}
\end{array}\right)+\left(\begin{array}{cc}
\psi_{11}^{1} & 0 \\
0 & \psi_{22}^{1}
\end{array}\right)\left(\begin{array}{c}
l y_{t-1} \\
l x_{t-1}
\end{array}\right)+\left(\begin{array}{cc}
\psi_{11}^{2} & 0 \\
0 & \psi_{22}^{2}
\end{array}\right)\left(\begin{array}{c}
l y_{t-2} \\
l x_{t-2}
\end{array}\right)+\left(\begin{array}{c}
\omega_{1 t} \\
\omega_{2 t}
\end{array}\right)
$$

$\mathrm{H}_{0}^{1}$ ve $\mathrm{H}_{0}^{2}$ için test istatistikleri ise standart $\mathrm{F}$ dağılımına uyarlar ve T toplam gözlem sayısı, p gecikme değeri olmak üzere aşağıdaki gibi gösterilirler:

$$
\begin{gathered}
\mathrm{F}_{\text {lex }_{\mathrm{t}} \rightarrow \mathrm{y}_{\mathrm{t}}}=\frac{\left(\sum_{\mathrm{t}=1}^{\mathrm{T}} \omega_{1 \mathrm{t}}^{2}-\sum_{\mathrm{t}=1}^{\mathrm{T}} \mathrm{v}_{1 \mathrm{t}}^{2}\right) / \mathrm{p}}{\left(\sum_{\mathrm{t}=1}^{T} v_{1 \mathrm{t}}^{2}\right) /(\mathrm{T}-2 \mathrm{p}-1)} \\
\mathrm{F}_{\mathrm{y}_{\mathrm{t}} \rightarrow \operatorname{lex}_{\mathrm{t}}}==\frac{\left(\sum_{\mathrm{t}=1}^{\mathrm{T}} \omega_{2 \mathrm{t}}^{2}-\sum_{\mathrm{t}=1}^{\mathrm{T}} \mathrm{v}_{2 \mathrm{t}}^{2}\right) / \mathrm{p}}{\left(\sum_{\mathrm{t}=1}^{\mathrm{T}} \mathrm{v}_{2 \mathrm{t}}^{2}\right) /(\mathrm{T}-2 \mathrm{p}-1)}
\end{gathered}
$$

Granger nedensellik testi literatürde sık kullanılmasına karşın durağanlık ve eşbütünleşme kavramlarının keşfedilmesi ile yeniden ele alınarak güncellenmesi gerekmekte idi. Keza Park ve Phillips (1989) ve Sims, Stock ve Watson (1990) çalışmaları Granger nedensellik testinin durağan olmayan seriler ile asimptotik olarak standart dağılımların hiçbirine uymadığını göstermiştir. Buradan hareketle Toda ve Yamamoto (1995) çalışması durağan olmayan ancak eşbütünleşik olan seriler için Granger nedensellik testini geliştirmiş ve yeni bir yöntem önermiştir. Bu yönteme göre ilk adımda seriler için belirlenen en iyi VAR modeline fazladan serilerin entegrasyon dereceleri kadar gecikme eklenerek oluşturulan yeni VAR modeli tahmin edilir. Örneğimizde iki gecikmeli bir VAR(2) modelinden faydalandik. Serilerin I(1) olduğu bilindiğine göre Toda ve Yamamoto (1995) yöntemi için VAR modeline bir gecikme daha eklenerek VAR(3) modeli kurup tahmin edilmelidir. Yöntemin ikinci aşamasında ise sonradan eklenen gecikmeli serilere ait parametreler hariç diğer parametrelere sıfır kısıı getirilerek yokluk hipotezi oluşturulur. Ardından yokluk hipotezine göre oluşturulan kısıtlı ve kisıtsız VAR modellerinden Wald istatistiği hesaplanır. Elde edilen bu Wald istatistiği standart $\chi^{2}$ dağlımına uymaktadır. Böylece durağan olmayan ancak eşbütünleşik olan seriler için de Granger nedensellik tanımı test edilebilir olmaktadır. Çalışmada Endonezya için üç diğer ülkeler için iki gecikmeli VAR modelleri tahmin edilmiş ve tüm ülkeler için değişkenler arasındaki tüm mümkün Granger nedensellik ilişkileri Toda ve Yamamoto (1995) yöntemi ile test edilmiştir. Sonuçlar Tablo 7'de gösterilmiştir. 
Tablo 7. Toda ve Yamamoto (1995) Nedensellik. Testi Sonuçar

\begin{tabular}{|c|c|c|c|c|}
\hline \multirow[b]{2}{*}{ Yokluk Hipotezleri } & \multicolumn{2}{|c|}{ Endonezya } & \multicolumn{2}{|c|}{ Meksika } \\
\hline & Test İstatistiği & p. Değeri & Test İstatistiği & p. Değeri \\
\hline $\operatorname{lex}_{t}$, ly $y_{t}$ 'ninGranger nedeni değildir. & 1.70 & 0.42 & $4.40^{* *}$ & 0.036 \\
\hline $\mathrm{ly}_{\mathrm{t}}$, lex $\mathrm{t}_{\mathrm{t}}$ 'ninGranger nedeni değildir. & $26.60 * * *$ & 0.00 & 2.00 & 0.15 \\
\hline $\lim _{t}, l_{t}$ 'ninGranger nedeni değildir. & 3.20 & 0.20 & 1.30 & 0.25 \\
\hline$l_{t}, \lim _{t}$ 'ninGranger nedeni değildir. & $30.40^{* * *}$ & 0.00 & $3.90^{* *}$ & 0.05 \\
\hline $\operatorname{lex}_{t}, \lim _{t}$ 'ninGranger nedeni değildir. & 4.40 & 0.11 & $5.70^{* * *}$ & 0.017 \\
\hline \multirow[t]{2}{*}{$\lim _{t}$, lex ${ }_{t}$ 'ninGranger nedeni değildir. } & 1.90 & 0.38 & 2.50 & 0.120 \\
\hline & \multicolumn{2}{|c|}{ Güney Kore } & \multicolumn{2}{|c|}{ Türkiye } \\
\hline Yokluk Hipotezleri & Test İstatistiği & p. Değeri & Test İstatistiği & p. Değeri \\
\hline $\operatorname{lex}_{t}, \mathrm{ly}_{\mathrm{t}}$ 'ninGranger nedeni değildir. & 1.10 & 0.29 & 0.31 & 0.58 \\
\hline $\mathrm{ly}_{\mathrm{t}}$, lex $\mathrm{t}_{\mathrm{t}}$ 'ninGranger nedeni değildir. & 0.28 & 0.59 & 0.045 & 0.83 \\
\hline $\lim _{t}, l_{t}$ 'ninGranger nedeni değildir. & 0.48 & 0.49 & $3.10^{*}$ & 0.08 \\
\hline$l_{t}, \lim _{t}$ 'ninGranger nedeni değildir. & 2.00 & 0.15 & 0.82 & 0.36 \\
\hline $\operatorname{lex}_{t}, \lim _{t}$ 'ninGranger nedeni değildir. & 1.90 & 0.17 & 0.01 & 0.99 \\
\hline $\lim _{t}$, lex $x_{t}$ 'ninGranger nedeni değildir. & 0.011 & 0.92 & 1.00 & 0.31 \\
\hline
\end{tabular}

-Yokluk hipotezinin; \%1 anlamlllı düzeyinde reddedilebildiği test istatistikleri (***) ile, \%5 anlamlllk düzeyinde reddedilebildiği test istatistikleri $\left(^{* *}\right)$ ile, \%10 anlamlllık düzeyinde reddedilebildiği test istatistikleri $(*)$ ile işaretlenmiştir.

Tablo 7'deki sonuçlara göre, Endonezya için gelirden ihracat ve ithalata doğru tek yönlü anlamlı iki nedensellik ilişkisi tespit edilebilmiştir. Meksika için ise ihracat gelirin, gelir ithalatın ve ihracat ithalatın Granger nedenidir. Güney Kore için istatistiki olarak herhangi bir anlamlı Granger nedensellik bulunamamıştır. Türkiye için ise sadece ithalattan gelire yönelik tek yönlü Granger nedeni değildir yokluk hipotezi ancak \%10 anlamllık düzeyinde reddedilebilmektedir. Bu sonuçları Granger'ın nedensellik tanımı çerçevesinde yorumlamak elzemdir. Değişkenler arasında anlamlı bir Granger nedenselliğin bulunamaması ilgili değisskenlerin birbirlerinden etkilenmedikleri anlamına gelmez. Tanımın 1şı̆̆ında yorumlamak gerekirse, Endonezya için gelirin, ihracat ve ithalat serilerinin öngörü performansı üzerinde istatistiki olarak dikkate değer bir katkısının olduğunu söyleyebiliriz. Benzer olarak, Meksika için gelir ve ihracat serilerinin ithalat serisinin öngörü hata varyansını düşürdüğü, ihracat serisinin ise gelirin öngörü performansını iyileştirdiği yorumu yapılabilir. Güney Kore için sistemde yer alan üç değişkenden herhangi birinin bir diğerinin öngörü performansı üzerinde anlamlı bir etkisinin olmadığı gözlenmiştir. Türkiye için ithalat serisinin gelirin öngörü bilgi kümesinde yer alması durumunda öngörü hata varyansını düşürdüğü bulgusuna ulaşılmıştır.

\section{Tartışma, Sonuç ve Öneriler}

Bu çalışmanın amacı, 1980-2017 yıllarını kapsayan dönem için MIST ülkelerinde ihracat, ithalat ve ekonomik büyüme arasındaki ilişkiyi Johansen Eşbütünleşme ve Toda ve Yamamoto yöntemlerini kullanarak test etmektir. Elde edilen sonuçları ülke bazı değerlendirdiğimizde GSYİH'sı dış ticaretten en çok etkilenen ülke Meksika'dır. Bu ülke için ihracatın $\% 1$ büyümesi geliri $\% 7.7$ arttıırken, ithalatın $\% 1$ büyümesi geliri $\% 6.5$ azaltmaktadır. Türkiye'de ithalat ve ihracat için tahmin edilen parametre değerlerinin mutlak değerce birbirine yakın olduğu gözlenmiştir. Bu durumun ortaya çıkması, ihracat içersindeki ithalat oranının payı ile ilişkilendirilebilir. Güney Kore'nin istatistiki olarak anlamsız bulunan parametre tahmini hariç tutulduğunda, diğer ülkeler için ihracatın gelir üzerindeki olumlu etkisi, ithalatın olumsuz etkisinden daha fazladır. Ancak Türkiye için bu farkın diğer ülkelere göre oldukça düşük olduğu görülmektedir. Çalışmada elde edilen nedensellik sonuçlarına göre, Endonezya için gelirden, ihracat ve ithalata doğru tek yönlü anlamlı iki nedensellik ilişkisi tespit edilmiştir. Meksika için ise ihracat gelirin, gelir ithalatın ve ihracat ithalatın Granger nedenidir. Türkiye için ise sadece ithalattan gelire yönelik tek yönlü Granger nedensellik ilişkisi tespit edilmiştir. Çalışmadan elde edilen sonuçlara göre Meksika, Endonezya ve Türkiye için dış ticarete dayalı büyüme hipotezi geçerlidir. Elde edilen bulgular, Fitzova ve Zidek (2015), Awokuse (2007), Chandra (2003), Shihab vd. (2014), Elbeydi vd. (2010), Shirazi ve Manap (2004), Raza ve Ying (2017), Hye vd. (2013), Nguyen (2016) çalışmalarındaki sonuçlarla benzerlikler içermektedir. Güney Kore için istatistiki olarak herhangi bir anlamlı Granger nedensellik bulunamamıştır. Bu sonuç, Zang ve Baimbridge (2012), Sharma ve Dhakal (1994) çalışmalarında elde edilen bulgularla benzerlik göstermektedir. Literatürdeki bazı çalışmalarda ticarete dayalı 
büyüme hipotezi ile tahmin edilen pozitif verimlilik etkilerinin özellikle gelişmekte olan ülkelerde meydana gelmediği görülmektedir. Bunun nedeni olarak bu ülkelerin ihracatında birincil (temel) malların büyük ölçüde rol almasıdır. Bu malların ihracatı büyük fiyat ve miktarsal dalgalanmalara yol açmaktadır. Ticaretin büyüme üzerindeki etkisinin ortaya çıkması için ülkelerin fiyat ve fiyat dışı yönleri geliştirilmelidir. Ayrıca ihracata konu olan malların ülke içerisindeki katma değerinin arttırlması gerekmektedir. Katma değeri düşük olan ürünlerin uluslararası piyasada daha az rekabet gücüne sahip olarak görünmesi de özellikle ticarete dayalı büyüme hipotezinin geçerli olmaması açısından önemli bir neden olduğu öngörülmektedir. Bununla birlikte ekonomik reformlar yapılarak ülkelerin ihracatının yüksek kalite içeren geniş ürün sepetine sahip olması uluslararası piyasada rekabet gücü açısından önem arz etmektedir. Bu durumun sağlanması ticaretin ekonomik büyüme üzerindeki beklenen olası etkileri arttırması mümkündür.

\section{Kaynakça}

Alam, M. S. (1991). Trade orientation and macroeconomic performance in LDCs: an empirical study. Economic Development and Cultural Change, 39(4), 839-848.

Amirkhalkhali, S. ve Dar, A. A. (1995). A varying-coefficients model of export expansion, factor accumulation and economic growth: Evidence from cross-country, time series data. Economic Modelling, 12(4), 435-441.

Awokuse, T. O. (2007). Causality between exports, imports, and economic growth: Evidence from transition economies. Economics letters, 94(3), 389-395.

Balassa, B. (1978). Exports and economic growth: Further evidence. Journal of development economics, 5(2), 181-189.

Balassa, B. (1985). Exports, policy choices, and economic growth in developing countries after the 1973 oil shock. Journal of development economics, 18(1), 23-35.

Çetintaş, H. ve Barışı, S. (2009). Export, import and economic growth: The case of transition economies. Transition Studies Review, 15(4), 636-649.

Chandra, R. (2003). Reinvestigating export-led growth in India using a multivariate cointegration framework. The Journal of Developing Areas, 37(1), 73-86.

De Gregorio, J. (1992). Economic growth in latin america. Journal of development economics, 39(1), 59-84.

Dickey, D. A. \& Fuller, W. A. (1979). Distribution of the estimators for autoregressive time series with a unit root. Journal of the American statistical association, 74(366a), 427-431.

Dickey, D. A. \& Fuller, W. A. (1981). Likelihood ratio statistics for autoregressive time series with a unit root. Econometrica: Journal of the Econometric Society, 1057-1072.

Dreger, C. \& Herzer, D. (2011). A Further Examination of the Export-Led Growth Hypothesis (Discussion Paper No. 305). Frankfurt: European University Viadrina.

Edeme, R. K., Ifelunini, I. A. ve Nkalu, N. C. (2016). A Comparative Analysis of the Impact of Agricultural Exports on Economic Growth of ECOWAS Countries. Acta Oeconomica Pragensia, 24(05).

Ee, C. Y. (2016). Export-led growth hypothesis: empirical evidence from selected Sub-Saharan African countries. Procedia Economics and Finance, 35, 232-240.

Ekanayake, E. (1999). Exports and economic growth in Asian developing countries: Cointegration and error-correction models. Journal of Economic Development, 24(2), 43-56.

Elbeydi, K. R., Hamuda, A. M. ve Gazda, V. (2010). The relationship between export and economic growth in Libya Arab Jamahiriya. Theoretical and Applied Economics, 17(1), 69-76.

Engle, R. F. ve Granger, C. W. (1987). Co-integration and error correction: representation, estimation, and testing. Econometrica: journal of the Econometric Society, 251-276.

Fitzová, H. ve Zídek, L. (2015). Impact of trade on economic growth in the Czech and Slovak Republics. Economics \& Sociology, 8(2), 36-50.

Foresti, P. (2006). Testing for Granger causality between stock prices and economic growth. MPRA Paper No. 2962.

Fosu, A. K. (1996). Primary exports and economic growth in developing countries. World Economy, 19(4), 465-475.

Furuoka, F. (2009). Exports and Economic Growth in ASEAN Countries: Evidence from Panel Data Analysis. The Icfai University Journal of Applied Economics, VIII(2), 7-16.

Granger, C. W. (1969). Investigating causal relations by econometric models and cross-spectral methods. Econometrica: Journal of the Econometric Society, 424-438.

Granger, C. W. ve Newbold, P. (1974). Spurious regressions in econometrics. Journal of econometrics, 2(2), 111-120.

Helpman, E. (1987). Imperfect competition and international trade: evidence from fourteen industrial countries. Journal of the Japanese and international economies, 1(1), 62-81.

Herzer, D. (2010). A further examination of the export-led growth hypothesis (Discussion Paper No. 200). Berlin: Ibero America Institute for Economic Research.

Hussain, M. A. ve Saaed, A. A. J. (2015). Impact of exports and imports on economic growth: Evidence from Tunisia. Journal of Emerging Trends in Economics and Management Sciences, 6(1), 13-21.

Hye, Q. M. A., Wizarat, S. ve Lau, W.-Y. (2013). Trade-led growth hypothesis: An empirical analysis of South Asian countries. Economic Modelling, 35, 654-660.

Iheanacho, E. (2017). ARDL approach to trade libralisation and economic growth in the developing country: Evidence from Nigeria. African Research Review, 11(2), 138-159. 
Ijirshar, V. (2015). The empirical analysis of agricultural exports and economic growth in Nigeria. Journal of Development and Agricultural Economics, 7(3), 113-122.

Johansen, S. (1988). Statistical analysis of cointegration vectors. Journal of Economic Dynamics and Control, 12(2-3), $231-254$.

Konya, L. (2004). Export-led growth, growth-driven export, both or none? Granger causality analysis on OECD countries. Applied Econometrics and International Development, 1(4), 73-94.

Kravis, I. B. (1970). Trade as a handmaiden of growth: Similarities between the nineteenth and twentieth centuries. The Economic Journal, 80(320), 850-872.

Mbaku, J. M. (1989). Export growth and economic performance in developing countries: further evidence from Africa. Journal of Development Economics, 14(2), 127-142.

Nelson, C. R. ve Plosser, C. R. (1982). Trends and random walks in macroeconmic time series: Some evidence and implications. Journal of Monetary Economics, 10(2), 139-162.

Newey, W. K. ve West, K. D. (1987). Hypothesis testing with efficient method of moments estimation. International Economic Review, 28(3), 777-787.

Nguyen H. T. (2016). Impact of export on economic growth in vietnam: empirical research and recommendations. International Business and Management, 13(3), 45-52.

Njimanted, G. F. ve Aquilas, N. A. (2015). The impact of timber exports on economic growth in Cameroon: an econometric investigation. Asian Journal of Economic Modelling, 3(3), 46-60.

Park, J. Y. ve Phillips, P. C. (1989). Statistical inference in regressions with integrated processes: Part 2. Econometric Theory, 5(1), 95-131.

Phillips, P. C. ve Perron, P. (1988). Testing for a unit root in time series regression. Biometrika, 75(2), 335-346.

Ram, R. (1985). Exports and economic growth: Some additional evidence. Economic Development and Cultural Change, 33(2), 415-425.

Ramos, F. F. R. (2001). Exports, imports, and economic growth in Portugal: evidence from causality and cointegration analysis. Economic Modelling, 18(4), 613-623.

Raza, M. ve Zhang Ying, X. (2017). The causal relationship between export and economic growth of Pakistan. International Journal of Economics, Commerce and Management, 5(2), 210-231.

Şahbaz, A., Hüseyin, A. ve Yanar, R. (2014). Seçilmiş Asya ülkeleri için ihracata dayalı büyüme modeli: Panel eşbütünleşme ve nedensellik analizi. Yönetim ve Ekonomi Araştırmalar Dergisi, 12(22), 24-46.

Sharma, S. C. ve Dhakal, D. (1994). Causal analyses between exports and economic growth in developing countries. Applied Economics, 26(12), 1145-1157.

Shihab, R. A., Soufan, T. ve Abdul-Khaliq, S. (2014). The causal relationship between exports and economic growth in Jordan. Global Journal of Management And Business Research, 14(3), 17-22.

Shirazi, N. S. ve Manap, T. A. A. (2004). Exports and economic growth nexus: The case of Pakistan [with comments]. The Pakistan Development Review, 43(4), 563-581.

Sims, C. A. Stock, J. H., ve Watson, M. W. (1990). Inference in linear time series models with some unit roots. Econometrica: Journal of the Econometric Society, 113-144.

Stiglitz, J. E. (2006). Making globalization work. New York: WW Norton \& Company.

Toda, H. Y. ve Yamamoto, T. (1995). Statistical inference in vector autoregressions with possibly integrated processes. Journal of Econometrics, 66(1-2), 225-250.

Topall, N. ve Alagöz, M. (2015). Gelişmekte Olan Ülkelerde İhracat, İthalat ve Ekonomik Büyüme İlişkisi: Panel Eşbütünleşme ve Panel Nedensellik. International Journal of Social and Economic Sciences (IJSES)(2), 122-126.

Tyler, W. G. (1981). Growth and export expansion in developing countries: Some empirical evidence. Journal of Development Economics, 9(1), 121-130.

Yardımcıoğlu, F. ve Gülmez, A. (2013). Türk Cumhuriyetlerinde ihracat ve ekonomik büyüme ilişkisi: Panel eşbütünleşme ve panel nedensellik analizi. Bilgi Ekonomisi ve Yönetimi Dergisi, 8(1), 145-161.

Zang, W. ve Baimbridge, M (2012). Exports, imports and economic growth in South Korea and Japan: a tale of two economies. Applied Economics, 44, 361-372.

\section{EXTENDED ABSTRACT}

The impact of trade on economic growth is an important issue of economic research. The growth performances experienced by the eastern Asian countries in the last half century have attracted the attention of economists. These developments have strengthened the claims of those who advocate free trade, in other words, the liberalization of the flow of goods and services on a global scale. Thus, the view that developing countries could only achieve high prosperity by adopting the idea of free trade was dominant in the literature. The removal of barriers to trade contributes to economic growth in many ways. For instance, idea of competition dominates the market with free trade. This approach leads to more efficient sharing and use of resources in economic activities. Countries that use their resources more efficiently can produce at lower cost and benefit from the advantages of the scale economy. In addition, experience, knowledge and technology transfers from international markets lead to higher growth rates in labor intensive economies. 
In this study, following the relevant literature, it was investigated whether the trade-based growth hypothesis was valid in the countries of MIST (Mexico, Indonesia, South Korea and Turkey) in light of the current data. The study of this hypothesis also allowed us to see the relations between imports, exports and economic growth. The MIST countries selected for the research have a serious production and consumption capacity due to their high population of young individuals. For this reason, MIST economies are expected to have an important impact on global trade today and in the future. The first part of the study focused on the relationship between foreign trade and economic growth. In the second part, detailed information about the data and method is given and empirical studies on the subject are given. Empirical findings, assessments and comments are included in the last section.

It is possible to divide the studies focusing on the relationship between foreign trade and economic growth into three groups. The first of these groups discussed the relationship between the mentioned cases with correlation analysis and the second group studies benefited from regression analysis. In the third group, it is possible to find various applications of time series methods which are used extensively in recent years. In this study, relationship between the foreign trade and economic growth in the focusing countries was examined by logarithms of total import, export and aggregate income variables which are measured with 2010 prices. Series used in the study that observed in the years 1987-2017 for Turkey, 1980-2017 for other countries. All data is available in the World Bank World Development Indicators database. The first phase of empirical study is the stationary analysis of series. Before the application of time series methods, this analysis is essential. The direction of the research is determined according to the results of the unit root tests. It was concluded that all series are first difference stationary. This means that classical methods cannot be applied to the series. For this reason, the Johansen method was used for the cointegration analysis and the TodaYamamoto (1995) method was used instead of the classical Granger causality test for causality analysis. Regression model estimates cannot be performed with non-stationary series. Instead, cointegration analysis could be used. The concept of cointegration claims that long-term relationships between economical variables can be predicted if they are affected by common shocks in the long term and move together. For this reason, it was tested whether there were significant cointegration relationships between foreign trade and income series for all MIST countries, and the estimates of long-term and short-term relationship coefficients were obtained. Causality relations between the series were investigated after the cointegration analysis. The definition of causality in the framework of economics and econometrics needs to be emphasized. According to Granger, a time series of $\mathrm{X}$ to be the cause of $\mathrm{Y}$, if it must have a statistically significant and positive effect on prediction performance of $\mathrm{Y}$. In this study, it is essential to think about causality in this context. Because the absence of a causal relationship between variables cannot be interpreted as a direct relationship between the variables. According to the findings obtained in the empirical study, there is a significant cointegration relationship between the foreign trade variables and the income variable for all countries examined. According to the estimated error correction models, error correction mechanism is working for these four countries. Estimation results of error correction models state that short-term parameter estimate of export is statistically significant for Mexico, short-term parameter estimates of import and income are significant for Turkey and income variable's short-term parameter estimate is significant for South Korea. In the estimation of long-term relationships, parameter estimations were found to be statistically significant for all countries except South Korea's export variable parameter estimation. According to this one percent growth in exports increases total income approximately $3.5 \%$ in Turkey. On the other hand, one percent growth in imports decreased aggregate income by 3.3 percent. According to the causality test, there was a significant two oneway causality relationship from total income to export and total income to import for Indonesia. When Mexico is analyzed, it is seen that export causes to income, income causes to imports and export causes to imports. It was only detected one-way Granger causality comes from imports to total income for Turkey. Finally, no significant Granger causality was found for South Korea. According to the results obtained, the parameter estimates showing the impact of imports and exports on total income in Turkey were found to be close to each other by absolute value. This result can be associated with the fact that Turkey's exports are significantly dependent on imports. Besides South Korea, the positive impact of exports on total income in other countries is greater than the negative impact of imports. For Turkey, however, this difference is relatively small compared to other countries. 